\title{
A cigaretta, az elektromos cigaretta és a vízipipa egészségre gyakorolt hatása
}

\author{
Farkas Árpád dr. ${ }^{1}$ - Tomisa Gábor dr. ${ }^{2}$ - Kis Erika dr. ${ }^{3}$ - Horváth Alpár dr. ${ }^{2}$ \\ ${ }^{1}$ Energiatudományi Kutatóközpont, Budapest \\ ${ }^{2}$ Chiesi Hungary Kft., Budapest \\ ${ }^{3}$ Babeș-Bolyai Tudományegyetem, Biológia és Geológia Kar, Kolozsvár, Románia
}

\begin{abstract}
A dohányzás káros hatásainak vizsgálata hosszú ideje az orvostudomány egyik legintenzívebben kutatott területe. A nagy tudományos érdeklődésnek köszönhetően ma már meggyőző evidenciák állnak rendelkezésre a hagyományos cigaretta használatának számos negatív hatásáról. Ezzel ellentétben a sokkal később bevezetett helyettesítő termékek veszélyeiről lényegesen kevesebbet tudunk. E körbe tartozik a manapság egyre népszerúbb elektromos cigaretta is, amelyre egyre több, egészségügyi kockázatot felmérô munka fókuszál. Ugyanakkor a több évszázados múltra visszatekintő és a világ bizonyos helyein sokáig népszerú vízipipa érdekes esetnek számít, mivel használóinak száma a nyugati világban az utóbbi időben megugrott, de az emberre gyakorolt hatása számos ponton még vita tárgyát képezi. A jelen munka célja, hogy a hazai és a nemzetközi szakirodalom alapján feltérképezze a hagyományos cigaretta, az elektromos cigaretta és a vízipipa fontosabb egészségügyi hatásait, és rámutasson azokra a kapcsolódó területekre, ahol további kutatások szükségesek. A szakirodalmi áttekintés során a különböző publikációs adatbázisokban fellelhető tudományos cikkeket elemeztük. A megvizsgált szakirodalom alapján a tartós dohányzásnak bizonyítottan a szív-ér rendszert és a légzőrendszert károsító hatása van, de növekvő számú bizonyíték utal a neurológiai káros hatásokra és a gasztroenterológiai hatásokra is. Ugyanakkor az elektromos cigaretta és a vízipipa esetében a bizonyított akut hatások mellett a hosszú távú hatásokat illetően további intenzív kutatásokra van szükség. Az elektromos cigaretta és a vízipipa esetében a hosszú távú hatások kapcsán a meggyőző evidencia hiánya semmiképpen nem jelenti azt, hogy ezen termékeket kockázatmentesnek kellene tekinteni, sőt a pulmonológusoknak és a döntéshozóknak mindent meg kell tenniük annak érdekében, hogy valamennyi dohánytermék törvényi szabályozása azok használatának visszaszorítását célozza. A kérdés fontosságának a COVID-19-pandémia különös aktualitást ad.
\end{abstract}

Orv Hetil. 2021; 162(3): 83-90.

Kulcsszavak: hagyományos cigaretta, elektromos cigaretta, vízipipa, biológiai hatás

\section{Health effects of cigarettes, electronic cigarettes and waterpipes}

Revealing the health effects associated with smoking has been in the focus of intense research for decades. Due to these research efforts, there is a convincing evidence regarding the negative effects of conventional cigarettes. However, much less is known about the replacement products such as electronic cigarettes. Moreover, the effects of waterpipes are also not fully explored, in spite of their long history. The scope of the present work is to survey the open literature to map the knowledge related to the health effects of conventional cigarettes, e-cigarettes and waterpipes. The analysis of the related scientific literature was performed based on papers retrieved in large publication repositories. Based on the reviewed literature, long-term smoking has demonstrated adverse effects on the respiratory as well as the heart and circulatory systems. In addition, the correlation between cigarette smoking and some gastroenterological and neurological diseases is also increasingly evident. By the same token, though the acute effects of e-cigarette and waterpipe are well documented, the protracted effects are still to be explored. The lack of pertinent information regarding the late effects of e-cigarette and hookah does not imply that there is no health risk associated with their consumption. On the contrary, in addition to the regular antismoke measures, pulmonologists and policy makers should do everything to lower the consumption of these alternative products.

Keywords: conventional cigarette, electronic cigarette, waterpipe, biological effect

Farkas Á, Tomisa G, Kis E, Horváth A. [Health effects of cigarettes, electronic cigarettes and waterpipes]. Orv Hetil. $2021 ; 162(3): 83-90$.

(Beérkezett: 2020. október 9.; elfogadva: 2020. november 14.) 


\section{Rövidítések}

$\mathrm{COHb}=$ (carboxyhemoglobin $)$ szén-monoxid-hemoglobin; COPD $=($ chronic obstructive pulmonary disease $)$ krónikus obstruktív tüdőbetegség; COVID-19 = (coronavirus disease 2019) koronavírus-betegség 2019; CRD = Centre for Reviews and Dissemination; DARE $=$ Database of Abstracts of Reviews of Effects; DLCO = (diffusing capacity for carbon monoxide) szén-monoxid-diffúziós kapacitás; EPA = $($ Environmental Protection Agency, United States of America) Környezetvédelmi Hivatal, Amerikai Egyesült Államok; EVALI = (electronic cigarette and vaping associated lung injury) e-cigarettával és/vagy vaporizálással összefüggésbe hozható tüdőkárosodás; $\mathrm{FEF}_{25-75}$ $=$ (forced expiratory flow at $25 \%$ and $75 \%$ of the pulmonary volume $)$ maximális középkilégzési áramlás; $\mathrm{FEV}_{1}=($ exhaled air volume in the first second of forced expiration) az első másodpercben mért eróltetett kilégzési térfogat; FRC = (functional residual capacity) funkcionális residualis kapacitás; $\mathrm{FVC}=$ (forced vital capacity) eróltetett vitálkapacitás; NHS EED = National Health Service Economic Evaluation Database; PEF $=($ peak expiratory flow $)$ kilégzési csúcsáramlás; $\mathrm{RV}=($ residual volume) residualis térfogat; SARS-CoV-2 = (severe acute respiratory syndrome coronavirus 2 ) súlyos akut légzőszervi szindrómát okozó koronavírus- $2 ; \mathrm{WHO}=($ World Health Organization) Egészségügyi Világszervezet

A több mint 7000 kémiai vegyületet tartalmazó dohányfüst súlyos betegségek okozója, számos, élettartamot megrövidítő és életminőséget rontó hatása ismert. Nem véletlen, hogy a dohánytermékek egészségre gyakorolt hatása a legintenzívebben kutatott területek egyike. Csupán a PubMed Central archívuma több mint 200 000, a cigaretta hatásával kapcsolatos publikációt tartalmaz. A hagyományos cigarettánál sokkal később megjelenő, ugyanakkor növekvő népszerúségnek örvendő elektromos cigarettához kötődő kutatások volumene lényegesen kisebb (például az említett PubMed Central 3300 körüli mûvet jegyez), de erőteljesen gyarapszik. Hasonló nagyságrendű kutatás foglalkozik a közel félezer éves múltra visszatekintő vízipipázás egészségügyi aspektusaival. Ugyanakkor fontos megjegyezni, hogy viszonylag kevés mú célozza meg a három terméknek és hatásaiknak a párhuzamba állítását. A jelen tanulmány célja, hogy a hazai és a nemzetközi szakirodalom alapján bemutassa mind a hagyományos, mind az említett alternatív dohánytermékek egészségügyi hatásait, és rámutasson azokra a területekre, ahol további kutatások szükségesek. Ugyancsak fontos megemlíteni, hogy az utóbbi időben egyre nagyobb népszerüségnek örvendenek a hevített dohánytermékek (heat-not-burn); az ezek egészségügyi kockázatát vizsgáló szakirodalom növekvő, de még így is szegényes. Éppen ezért a jelen munkánkban a hagyományos cigaretta, az elektromos cigaretta és a vízipipa hatásai kerülnek górcső alá.

A nemzetközi irodalom áttekintése során a PubMed, az EBSCO, a Web of Knowledge és a CRD (DARE + NHSEED) adatbázisokat használtuk. Általános elv volt, hogy az idézett cikkek csak akkor lehetnek 5-6 évnél régebbiek, ha a felhasznált adat releváns, és nem található meg újabb kutatásokban. Előnyben részesítettük továbbá a lektorált, magasabb impaktfaktorú folyóiratokban megjelent munkákat, valamint az összefoglaló cikkeket. A felhasznált eredmények esetében releváns volt az esetszám, amelyre az adott adat vonatkozott, illetve a metaanalízisekből és az összefoglaló cikkekből származó adatok esetében az áttekintett cikkek mennyisége, összesetszáma és összimpaktfaktora is mérvadó volt. A keresések kulcsszavasak voltak, többek között a „cigarette”, „e-cigarette”, „electronic cigarette”, „hookah”, "waterpipe”, „health effects”, „circulatory”, „respiratory”, „pregnancy”, „cancer”, „asthma”, „COPD”, „lung function”, „birth defect”, „COVID-19” stb. szavakat és kifejezéseket használtuk „és” vagy „vagy” logikai összekapcsolással. A találatokat két szerző egymástól függetlenül szúkítette azok relevanciája alapján, s a végén a kiválasztás az összes szerző konszenzusán alapult. Az idézett magyar szakirodalom egy kivétellel az Orvosi Hetilap és a Medicina Thoracalis tudományos folyóiratok utolsó ötévi kiadásaiból származik.

\section{A hagyományos cigaretta egészségügyi hatásai}

Ugyan a cigarettahasználat gyakorisága kontinensról kontinensre és országról országra változik, a Világbank kimutatása szerint a világ felnőtt lakosságának mintegy 20\%-a dohányzik (a férfiak 35\%-a, a nők 6\%-a) [1]. Ugyanezen forrás szerint hazánkban a dohányosoknak a teljes felnőtt lakosságra vetített aránya az 1980-90-es évekhez képest lényegesen csökkent, de 2016-ban még így is $30,6 \%$ volt. A cigarettázó férfiak száma a világban szinte mindenhol meghaladja a nókét, de a skandináv országokban a két populáció közel azonos számú. Mint már említettük, számos tanulmány foglalkozik a cigarettához köthető egészségügyi hatásokkal. A cigarettázást többek között összefüggésbe hozták számos neurológiai, szív- és érrendszeri, valamint légúti betegség kialakulásával.

\section{Neurológiai hatások}

Egy 2017-ben született összefoglaló tanulmány szerint statisztikailag szignifikáns korreláció mutatható ki az elszívott cigaretta mennyisége, valamint a depresszió és a szorongás gyakorisága között [2]. Továbbá Boksa (2017) munkája rávilágít a cigarettázás és a pszichiátriai problémák közötti erős kapcsolatra [3]. Míg a dohányzás és a Parkinson-kór között negatív korrelációt találtak [4], addig a dohányzás és az Alzheimer-kór kapcsolata ellentmondásos.

\section{Szin-és érrendszeri hatások}

A cigarettázás hatással van a szív funkciójára és a keringésre. A nikotinnak vasoconstrictiv hatása van, a $\mathrm{CO}$ pe- 
dig kötődik a hemoglobinhoz és a mioglobinhoz, csökkentve az artériás $\mathrm{O}_{2}$-szaturációt [5]. Kimutatásra került, hogy a cigarettázás növeli a nyugalmi szívritmust és csökkenti a terhelésest [6]. Az aktív dohányosoknál a hypertensio kockázata magasabb. Rendszeres dohányzás hatására a szív- és érrendszeri betegségek valószínúsége szignifikánsan megnő. A cigarettázás növeli a stroke, a szívinfarktus és a szívkoszorúér-betegség kockázatát [7]. A patomechanizmusban jelentős szerepet játszanak a füsttel bekerülő szabad gyökök, melyek oxidatív stresszt okoznak. A reaktívoxigén-származékok a véráramba kerülve modulálják az antioxidánsenzim-aktivitást, ami cardiovascularis károsodást okoz [8].

\section{Légzörendszeri hatások, COPD, asztma és tüdörák}

Mivel a cigarettafüstben lévő káros anyagok belégzés által közvetlenül a légutakba kerülnek, nem meglepó, hogy a káros hatásoknak egyik leginkább kitett szerv a tüdő. A dohányzás miatt megnövekedett valószínűséggel kialakuló légúti betegségek közül kiemelkedik a COPD (krónikus obstruktív tüdőbetegség), az asztma és a tüdőrák. A WHO szerint a COPD legfontosabb kiváltó oka a dohányzás (beleértve a passzív dohányzást is). Számos tanulmány (például a „Rotterdam study”) megállapította, hogy a COPD prevalenciája az aktív dohányosok körében a legmagasabb, amit a volt dohányosok és a nem dohányzók követnek [9]. A magasabb prevalencián túlmenően a COPD miatti halálozási ráta is magasabb a cigarettázók körében, mint a nem dohányzók között. A leszokás sok jótékony hatása közül kiemelkedő az a megfigyelés, miszerint ha a dohányos COPD-s idejében abbahagyja a dohányzást, az elvesztett légzésfunkciót nem nyeri ugyan vissza, de a kor előrehaladásával a további csökkenés üteme közel azonos a nem dohányzókra jellemző funkciócsökkenés rátájával [10]. A cigarettafüst által indukált COPD patogenezisének minden részlete még nem ismert, de tudható, hogy a cigarettafüstben található számos összetevő ( $10^{15}$ szabad gyök/puff) a légutakban oxidatív stresszt indukál [11]. A fenntartott oxidatív stressz többek között apoptózist és krónikus gyulladást okoz, amelyek fennállnak a dohányzás abbahagyása után is. A gyulladásos sejtek számos olyan proteázt (fehérjebontó enzim) bocsátanak ki, amelyek károsítják az extracelluláris mátrixot, és emphysemát idézhetnek elő. A gyulladásnak a szövetkárosodást okozó kaszkádot beindító szerepe azonban az utóbbi időben megkérdőjeleződött. Helyette inkább az valószínű, hogy a gyulladás már a destrukció következménye és közben további sérülések forrása. A megnövekedett apoptózis miatti sejtvesztés szintén felelős lehet a szövetkárosodás beindításáért. Bizonyos kutatások az alvósejtek szerepét hangsúlyozzák, amely kapcsolatban áll a dohányzás hatására csökkenő tendenciát mutató öregedésgátló molekulákkal. Az alvósejtek számos gyulladásos fehérjét bocsátanak ki [12]. A legújabb kutatások szerint ugyanakkor a cigarettafüst okozta mitokondrium-autofágia programozott nekrózist indukál, s ez számos gyulladást segítő anyagot és olyan perzisztens gyulladást idéz elö, amely nem magyarázható az apoptotikus sejthalállal [13].

A cigarettázóknak 30 év felett átlagosan évi 40-45 ml-rel csökken a $\mathrm{FEV}_{1}$-ük a nem cigarettázók átlagos 30 ml-éhez képest, sőt a fiatal dohányosoknál a visszaesés is hamarabb (kb. 20. életév) elkezdődik [14]. Továbbá a légzésfunkció csökkenését passzív dohányosoknál is kimutatták [15]. A dohányzás ugyanakkor nemcsak a légzésfunkció romlását hozza, hanem megnövelheti az asztma kialakulásának kockázatát is. Ez különösen igaz a fiatalkori dohányzás esetében, de kapcsolat valószínűsíthető a felnőttkori asztma kialakulása és a dohányzás között is [16]. A dohányzó asztmások külön fenotípusként kezelendők, mivel esetükben az alkalmazott kortikoszteroid hatása elmarad a nem dohányzóknál tapasztalt hatástól. A dohányzás abbahagyása esetén csökkennek a tünetek, nő az asztmakontroll szintje, javulnak a légzésfunkciós értékek [17]. Ugyanakkor a gyerekkori passzív dohányzás, de fóképp a terhes anya cigarettázása szignifikáns kockázati faktora az asztmának [18]. Fontos megjegyezni, hogy a dohányzás nemcsak elősegítheti az asztma kialakulását, hanem súlyosbítja is azt, ha a dohányos továbbra sem hagyja abba a cigarettázást. Kimutatták, hogy az asztmás dohányosok asztma miatti mortalitása nagyobb, mint a nem dohányzó asztmásoké [19]. Egy nagy esetszámú hazai tanulmány vizsgálta az asztmások dohányzási szokásait és ezek hatását az asztmakontrollra. Annak ellenére, hogy jelentős részük érzékenyen reagál a dohányfüstre (ami az asztma patofiziológiájából is adódik), a bevont betegek 13,1\%-a aktív dohányos volt, míg 20,3\%-uk dohányzott a betegsége korábbi szakaszában. A dohányzás volt az elhízás mellett a leggyakrabban tapasztalt rizikófaktor a rossz kontroll tekintetében [20].

Az Egyesült Államok Környezetvédelmi Hivatala (EPA) szerint a tüdőrák miatti halálozásért 80-90\%-ban a dohányzás felelős. A második ok a radon, de ha a kettő együtt van jelen, akkor a kockázat potencírozódik [21]. Ugyanakkor a passzív dohányzás és a tüdőrák kockázata közötti kapcsolatot kereső tanulmányok időnként ellentmondásos eredményre jutnak. Ennek ellenére az EPA, a Nemzetközi Rákkutató Hivatal és sok más intézmény a passzív dohányzást is a tüdőrák kockázati tényezőjévé nyilvánította. Fontos megjegyezni azt is, hogy az EPAkiadvány óta eltelt időben egyre növekszik a légszennyezés miatti tüdőrákos esetek száma, tehát a dohányzásnak mint a tüdőrák kockázati tényezőjének a relatív aránya csökkenhetett.

\section{A terhesség, a szülés, a születési rendellenességek és a dohányzás kapcsolata}

A terhesség előtti és alatti aktív vagy passzív dohányzás és a magzat terhesség alatti állapota, a szülés kapcsán fellépő komplikációk és a magzat születési rendellenességei 
közötti kapcsolatot számos munka vizsgálta. Ismert tény, hogy a várandósság alatti dohányzás növeli a szülészeti komplikációk (például abruptio placentae, idő előtti burokrepedés) veszélyét. A dohányzás miatti koraszüléssel és a csökkent születési testtömeggel született csecsemők adják a csecsemők morbiditásának és mortalitásának jelentős hányadát [22]. A várandós anya dohányzása szignifikánsan növeli a magzat szervi betegségei kialakulásának a valószinűségét, de érzelmi és magatartásbeli zavarok is gyakrabban fordulnak elö. Ugyanakkor nemcsak a terhesség alatti, hanem a terhesség előtti dohányzásnak is negatív hatásai vannak. Egy, másfél millió várandós nôn elvégzett tanulmány szerint a fogamzás előtti hónapokban történő dohányzás még akkor is megnöveli bizonyos magzati anomáliák valószínûségét, ha a teherbe esés után a dohányzás abbamarad [23].

\section{A dohányzás és a gasztroenterológiai betegségek}

A dohányzás a rizikófaktora számos gyomor-bél rendszeri betegségnek, mint például a gyomor-, nyelőcső- és vastagbélrák, a gyomorfekély vagy a gyulladásos bélbetegségek, mint a Crohn-betegség vagy az ulcerativ colitis. Érdekes módon ez utóbbi két betegség esetében a dohányzás ellentétes kockázati tényezőként van számontartva, vagyis míg a dohányzás növeli a Crohn-betegség kialakulásának veszélyét és súlyosságát, addig a nem specifikus vastagbélfekély kockázata a nem dohányzók esetében magasabb [24]. Ugyan több egymást nem kizáró magyarázat is született a dohányzás és e két betegség eltérő kapcsolatára (például különböző helyen alakulnak ki, különböző az etiológiájuk, különböző az immunválasz), mechanizmusokon alapuló, egységes magyarázó elmélet a mai napig nem létezik.

\section{A cigarettázás és a koronavirus-betegség (COVID-19)}

A jelenlegi koronavírus-világjárvány alatt számos olyan kutatás indult el, amely a hagyományos dohányzás és a SARS-CoV-2 által okozott betegség kapcsolatát vizsgálja. Ugyan a dohányzás és az infekció kockázata közötti összefüggés ma még képlékeny, számos tanulmány bizonyítja, hogy fertőződés esetén a korábbi és az aktuális dohányzás is növeli a COVID-19 súlyos kimenetelének kockázatát. A jelenleg is dohányzó COVID-19-betegek mortalitása is nagyobb, mint a nem dohányzóké [25]. Ugyanakkor azt is kimutatták, hogy a komorbiditások növelik a betegség súlyos kimenetelének veszélyét [26]. Az a tény, hogy a komorbiditások egy részéért is a dohányzás lehet a felelős, rámutat a cigaretta és a COVID-19 lefolyása közötti kapcsolat komplexitására, amely minden bizonnyal további kutatások tárgya lesz a jövőben.

\section{Az elektromos cigaretta egészségügyi hatásai}

A világ számos országában a dohányzás visszaszorítása érdekében történt erőteljes fellépéseknek köszönhetően csökkent a dohányzási kedv. Válaszként a dohányipar a kieső jövedelem pótlására alternatív dohánytermékek kifejlesztésébe kezdett. Ugyan az első próbálkozások egészen az 1960-as évekig nyúlnak vissza, a kereskedelmi forgalomba is került, mai értelemben vett elektronikus cigarettáról 2003 óta beszélhetünk [27]. A meghatározás szerint az elektromos cigaretta olyan, egyszer használatos vagy utántöltő flakonnal és tartállyal vagy egyszer használatos patronokkal utántölthető elektronikus eszköz, amely szipkán keresztül nikotintartalmú vagy nikotinmentes pára fogyasztását teszi lehetővé. Fontos különbség a cigarettához képest, hogy az elektromos cigarettának (egyéb nevei: e-cigaretta, e-cigi, e-vape, e-hookah, páratoll) nem füstje, hanem párája van, ezért mellékfüstje sincs, de exhalált e-cigaretta-aeroszolról már beszélhetünk. Fontos megjegyezni, hogy az elektromos cigaretta elterjedését fóleg a kezdetekkor, de bizonyos mértékben napjainkban is segíti, hogy sokan a hagyományos cigarettáról történő leszokást elősegítő eszközként tekintenek rá. Az e-cigaretta növekvő népszerúségét mi sem jelzi jobban, mint hogy 2011 és 2018 között az e-cigaretta-használók száma világviszonylatban meghatszorozódott [28]; ezen belül a legnagyobb növekedés a tinédzserek és a fiatal felnőttek esetében történt, akik eleve fogékonyabbak az okosított eszközökre és a köréjük szerveződő szociális média rezzenéseire. Az e-cigaretta-használókra egyébként is jellemző, hogy fiatalabbak, iskolázottabbak és magasabb jövedelmúek, mint cigarettázó társaik. Ugyan történtek előrelépések az elmúlt időszakban, de a cigarettához képest az e-cigaretta szabályozási háttere világviszonylatban nagyon gyenge. Ennek egyenes következménye, hogy számos ellenőrizetlen, az egészségre fokozottan káros anyagokat is tartalmazó termék kerülhet piacra mind legálisan, mind alternatív csatornákon. A rendelkezésre álló korlátozott tudás mellett ugyancsak az elégtelen szabályozás a felelős a szegényes tájékoztatásért a kapcsolódó egészségügyi kockázatok tekintetében.

A hagyományos cigarettához képest a viszonylag nem régóta piacon lévô és világszinten legalább 20-szor kevesebb ember által használt elektromos cigaretta egészségre gyakorolt hatását illetően növekvő, de lényegesen kevesebb evidencia áll rendelkezésre, mint a dohányzás hatásáról. Egy 2016-ban magyar nyelven megjelent öszszefoglaló közlemény [29] az akkori vonatkozó szakirodalmat áttekintve megállapította, hogy a pára beszívását követő obstruktív hatások megfeleltek a hagyományos cigaretta elszívása után tapasztaltaknak. A szerzők ebból arra következtetnek, hogy a hosszú távú használat során az e-cigaretta minden valószínúség szerint a hagyományos cigarettához hasonló elváltozásokat okozhat a tü- 
dőfunkcióban, valamint az e-cigaretta használata során a kilélegzett párában jelen lévő részecskék minden, zárt térben tartózkodó személy egészségére ártalmasak. Egy 2014-es in vitro kísérletben az e-cigaretta gőzének kitett bronchialis sejtek tenyészetén citokinek és gyulladásos mediátorok felszabadulását tapasztalták [30], de a citotoxicitás szignifikánsan kisebb volt, mint a hagyományos cigaretta esetében. Egy nemrég megjelent publikációban [31] laboratóriumi körülmények között az e-cigarettában jelen lévő mesterséges aromák negatívan befolyásolták a kitett humán légúti epithelialis sejtek csillószőreinek múk ödését. Az e-cigaretta hatását természetesen in vivo körülmények között is tanulmányozták. A legtöbb kutatás középpontjában az elektromos cigaretta szív- és érrendszeri, valamint légzőrendszeri hatásai álltak. Az elektromos cigaretta használatának következményeként egyes szerzők a szívritmus szignifikáns emelkedését és a diastolés vérnyomás emelkedését [32] tapasztalták. Egyes tanulmányok az e-cigaretta-használattal összefüggésbe hozható légúti ellenállás és impedancia növekedését mutatták ki, vagyis csökkent a légúti konduktancia. A cigaretta használata légúti obstrukcióban szenvedőknél rövid idôn belül ( 10 perc) a tünetek rosszabbodását (például köhögés, szívdobogás) okozta [33]. Míg a szívdobogás csak nikotinos e-cigaretta használata után jelentkezett, addig a tüdőfunkció romlása nikotinmentes e-cigaretta elszívását követően is megfigyelhető volt. Megjegyzendő, hogy az eredmények első generációs e-cigarettára vonatkoznak. Az újabb generációs e-cigaretták hatásairól még kevesebb adat áll rendelkezésre. A helyzet komplexitását tovább növeli, hogy bizonyos fiziológiai hatások a nikotinnak tulajdoníthatók, amelynek koncentrációja nagyon széles tartományon belül változhat az egyes termékek között. Pisinger és Døssing (2014), miután áttekintették a vonatkozó irodalmat (76 tanulmányt), megállapították, hogy a módszertani hibák, az eredmények ellentmondásossága, a termékek különböző összetétele, az előforduló összetevők koncentrációbeli nagy varianciája, a hosszú távú hatások ismeretének hiánya és számos esetben a szerzők dohányipari érdekütközései miatt nem lehet egyértelműen számszerúsíteni az elektromos cigaretta által kiváltott negatív hatásokat, de nem megalapozott azt kockázatmentesnek nyilvánítani sem [34]. Hasonló következtetésre jut az az Orvosi Hetilapban megjelent összefoglaló közlemény [35] is, amely megállapítja, hogy ugyan a COPD-s és asztmás betegeknél a hagyományosról az ecigarettára történő áttérés a légzésfunkció javulását és a fellángolások veszélyének csökkenését eredményezte, a hosszú távú használat hatásai nem ismertek. Említésre méltó egy másik magyar tanulmány is, amelyet 1445 résztvevőn végeztek, és amely a kettős (hagyományos és e-cigaretta) és a csak e-cigaretta-használók közötti különbségekre fókuszált [36]. Megállapítást nyert, hogy a tapasztalt káros hatások szignifikánsan magasabb számban fordultak elő a vegyes felhasználóknál, mint a csak e-cigarettázóknál. Az előbbieknél a leggyakrabban a kö- högés, míg az utóbbiaknál a szájszárazság és a torokirritáció jelentkezett. A vizsgálati alanyok többsége jobb légző, szagló és ízérzékelő funkcióról számolt be az ecigarettára való áttérés után, míg az étvágy, a szexuális teljesítmény és a memória terén történt javulásról kevésbé számoltak be. A felmérés alapján a csak e-cigarettát használók lényegesen jobb szájhigiéniával rendelkeznek, mint a kettős használók.

Végezetül az e-cigaretta egészségre gyakorolt hatásainak áttekintése nem nélkülözheti a 2019-ben az Amerikai Egyesült Államokban egészségügyi vészhelyzetet okozó, az e-cigarettával és/vagy vaporizálással összefüggésbe hozható tüdőkárosodás (EVALI, electronic cigarette and vaping associated lung injury) halmozódását, amely 2800 kórházi felvétellel és 68 halálos esettel járt. Az esetet rendkívül igényesen és mind társadalmi, mind tudományos szempontból precízen leíró és tárgyaló két magyar mú alapján $[37,38]$, ugyan az eseteket a kannabinoidok használatával és az E-vitamin-acetát-expozícióval hozták összefüggésbe, a technikai és szabályozási hiányosságok, a soktényezős lehetséges kórokok, a mintavételek standardizáltságának hiánya és egyéb tényezők kétségessé teszik a vonatkozó adatok validitását. Mindenesetre a 2020 elejére véget ért EVALI-járvány is rávilágított arra, hogy az e-cigaretta használata a jelenlegi rendkívül komplex technikai, szabályozási és piaci viszonyok és feltételek mellett nem tekinthető kockázatmentesnek.

\section{A vízipipa egészségügyi hatásai}

A vízipipának (egyéb nevei: hookah, shisha, goza, narghileh, arghileh, hubble-bubble) mint a dohány és egyéb anyagok egyik fogyasztási eszközének a pontos eredete tisztázatlan. A legtöbb tanulmány Indiából vagy Perzsiából származtatja, ahol több mint 400 éve használják. Az idők során nagy népszerúségnek örvendett az arab világban, Észak-Afrikában és Délkelet-Ázsiában, de a modern korban a használata egyre gyakoribbá vált Európában és Észak-Amerikában is. Jelenleg szinte a világ minden táján növekszik a prevalenciája, föleg a fiatalok körében. A 2012-13-ban elvégzett hazai felmérések azt mutatták, hogy a 13-15 éves korosztály 17-20\%-a használt vízipipát a megkérdezés időpontját megelőző 30 napban. Egy frissebb felmérésben [39] 996 magyar egyetemistából 57 $(5,7 \%)$ használt vízipipát (a férfiak 7,5\%-a, a nők 4,7\%-a) legalább havi egy alkalommal. Népszerúségéhez hozzájárul az a közhiedelem is, miszerint a vízipipa tartályában található vízen áthaladó füst kiszûri a káros anyagokat. Mindamellett, hogy a füstben található toxikus, karcinogén anyagok egy része valóban kiszürődhet, megállapítást nyert, hogy egy vízipipaszeánszon (20-80 perc) 100-200 hagyományos cigaretta elszívásakor bejutó füstmennyiség juthat a szervezetbe [40]. Természetesen a bevitt füst mennyisége és minősége nagymértékben függ a berendezéstől és a használt anyagoktól is. Azt is fontos megjegyezni, hogy a vízipipázáshoz köthető $\mathrm{CO}$ 
és egyéb káros (toxikus, karcinogén) anyag egy jelentős része nem a szájrészen át beszívott füstből, hanem a kehelyben történő égetésből származik. A hagyományos cigarettához hasonlóan, a füstben található káros anyagok egy jelentős része még nem ismert, de többek között azonosították a szén-monoxidot, a nikotint, a poliaromás szénhidrogéneket és a kátrányt. Ugyancsak megtalálható volt a füstben a mérgező és rákkeltő arzén, a mérgező, rákkeltő, tüdő-, szív- és vesekárosító kadmium, a tüdókárosító és potenciálisan rákkeltő nikkel, a rákkeltő formaldehid, a sejtméreg acetaldehid, a toxikus, vérképzést befolyásoló, idegrendszert károsító és potenciálisan rákkeltő ólom vagy a radiotoxikus és rákkeltő polónium (218-as izotóp). A felszabaduló anyagok fokozott karcinogén hatását az is okozza, hogy a vízipipa esetében az égés megközelítőleg mindössze $200{ }^{\circ} \mathrm{C}$-on történik a cigarettával szemben, amelynél a hőmérséklet eléri az 1000-1200 ${ }^{\circ} \mathrm{C}$-ot. A vízipipa és a cigaretta által kibocsátott $\mathrm{CO}$-expozícióval kapcsolatosan magyar kutatók [41] megállapították, hogy 3 cigaretta 60 perc alatt történő elszívása után a maximális kilélegzett $\mathrm{CO}$-szint 7,5-ször kisebb, mint ami 80 perc vízipipázás után jellemzi az exhalátumot (a két esetben azonos mennyiségú dohányt használtak). Ezenkívül, a vízipipázás utáni magas szén-monoxid-koncentráció tovább tart, mint a hagyományos cigarettázást követő emelkedett CO-koncentráció.

\section{Szív-és érrendszeri hatások}

A vízipipázásnak egyaránt vannak rövid és hosszabb távú szív- és érrendszeri hatásai. Az akut hatások közül megemlíthetjük a szívritmus 4-16/perccel, a systolés vérnyomás 6,7-15,7 Hgmm-rel, valamint a diastolés vérnyomás 2-14 Hgmm-rel történő növekedését [42]. Fontos megjegyezni, hogy míg a fenti effektusok már egyetlen alkalom után is jelentkeznek, vannak olyan hatások is, amelyek csak hosszabb távon, kellően sok szeánsz következményeként mutatkoznak. Hosszabb távon közepesen erôs vízipipások esetében (több mint 50 szeánsz/év) 1,8-szoros, erôs vízipipások esetében (legalább 180 szeánsz/év) 3,75-szörös infarktus- és ischaemiakockázatot tapasztaltak. Ha a szeánszok száma legalább 40/év volt, akkor a coronariastenosis kockázata 2,95-szörösre emelkedett a nem vízipipázók kockázatához képest [43].

\section{Légzörendszeri hatások}

$\mathrm{Az}$ érrendszeri hatásokhoz hasonlóan, a vízipipa légzőrendszeri hatásai azonnali és hosszabb távú hatásokra oszthatók. Az akut hatások közül a légzési frekvencia növekedését (percenkénti 2-3,5-del), valamint a PEF és $\mathrm{FEF}_{25-75}$ jelentős csökkenését tapasztalták, ugyanakkor a $\mathrm{FEV}_{1}, \mathrm{FVC}, \mathrm{FEV}_{1} / \mathrm{FVC}$ és DLCO nem változott szignifikánsan. Az egyéb megfigyelt, akut hatások közül említésre méltó a vízipipának betudható oxigénszaturációcsökkenés, valamint az emelkedett exhalált CO-szint és
COHb-vérszint, amely gátolja az oxigén szállítását (például az agyba) [44]. A COHb-szint emelkedése hosszú távon jelentősebb a vízipipázóknál, mint a cigarettázóknál, ugyanakkor a $\mathrm{FEF}_{25-75}, \mathrm{FEV}_{1}, \mathrm{FVC}$ és $\mathrm{FEV}_{1} / \mathrm{FVC}$ szignifikánsan csökken, az FRC és RV pedig nő [45]. Bizonyos kutatások kapcsolatot találtak a vízipipázás és a COPD kialakulása között [46]. A vízipipázás mennyisége és a tüdőrák közötti pontos kapcsolat feltárásához további tanulmányokra van szükség.

\section{Nyelöcsö-, gyomor-, húgyhólyag- és egyéb rákok}

Ugyan létezik evidencia a vízipipa és a különböző ráktípusok gyakoribb elöfordulása között, az ok-okozati öszszefüggés kevésbé van alátámasztva, mint a cigaretta esetében. Néhány tanulmányban kapcsolatot mutattak ki a vízipipázás és a nyelőcsőrák között [47], de volt olyan is, amelyik nem talált szignifikáns összefüggést. Hasonló módon, egyes tanulmányok összefüggést találtak a vízipipázás és a gyomorrák között, de más tanulmányok ezt nem igazolták. A cigarettával ellentétben kevés a bizonyíték a vízipipa és a húgyhólyagrák kapcsolatára vonatkozóan is. Hasonlóan, nincs jelenleg meggyőző evidencia ok-okozati összefüggésre a vízipipázás, valamint a prosztata-, a hasnyálmirigy- és a gégerák között [48].

\section{Szülési, születési rendellenességek}

A vízipipa és a születési rendellenességek közötti kapcsolat jelenleg nem teljesen tisztázott. Egyes tanulmányok rámutattak arra, hogy az anya vízipipázása nem okoz magzati sorvadást, de kimutatták az összefüggést az anya vízipipázása és a perinatalis légzési szövődmények között [49]. Egy másik kutatás alapján a vízipipázás csökkentette az in vitro megtermékenyítés esélyét [50].

Összefoglalva a nemzetközi szakirodalom alapján, a vízipipa káros voltára a legmeggyőzőbb evidencia az érés szívbetegségek, valamint a légzőrendszeri hatások tekintetében van. Számos egyéb betegség esetében fennáll a gyanú, hogy a vízipipázás növeli a kockázatot, de további nagy esetszámú, hosszú időtartamú felmérések szükségesek.

\section{Következtetések, kitekintés}

A jelen cikkben a cigarettából, az e-cigarettából és a vízipipából származó aeroszolrészecskék hatását tekintettük át. Szakirodalmi kutatásainkból kiderült, hogy a hagyományos cigarettának a szív-ér rendszert és a légzőrendszert károsító hatása van, de növekvő számú bizonyíték utal a neurológiai káros hatásokra és a gasztroenterológiai hatásokra is. Érdekes aktuális területnek számít a cigaretta és a COVID-19 kapcsolata, amely minden bizonynyal intenzív kutatási terület lesz a közeljövőben. 
Ugyan a cigaretta egészségre gyakorolt hatását illetően - amely hatalmas szakirodalommal rendelkezik - is van még számos kérdés, a bizonytalanság és az újabb kutatások szükségessége jóval nyilvánvalóbb az elektromos cigaretta és a vízipipa esetében. Az elektromos cigaretta és a vízipipa esetében a hosszú távú hatások kapcsán a meggyőző evidencia hiánya semmiképpen nem jelenti azt, hogy ezeket a termékeket kockázatmentesnek kellene tekinteni, sôt a pulmonológusoknak és a döntéshozóknak mindent meg kell tenniük annak érdekében, hogy valamennyi dohánytermék törvényi szabályozása azok használatának visszaszorítását célozza.

A biológiai hatások terén számos kérdés megválaszolására a légutakban leülepedő káros anyag pontos mennyiségének és térbeli (légzőrendszeri generáció szerinti) eloszlásának meghatározása jelenthet megoldást. A légúti depozíciót leginkább befolyásoló faktorok a légutak geometriai (morfometriai) méretei, az emittált aeroszolrészecskék fizikai jellemzői (méret, higroszkóposság, koagulációs képesség, sűrüség) és a légzést leíró adatok (a belégzés ideje, belélegzett levegőtérfogat, benntartási idő, kilégzési idő). A három termék használatát jellemzó eltérő légzési mintázatok feltérképezése, valamint az emittált részecskék aerodinamikai és egyéb fizikai tulajdonságainak feltárása a kutatócsoport által folyamatban van, és a jelen dolgozat folytatásának szánt munka részét képezi. Ugyancsak e munka eleme egy saját fejlesztésü részecskeülepedési tüdőmodellnek a hagyományos és az alternatív dohánytermékekre történő adaptációja és validálása. Ezek majd lehetővé teszik, hogy a cigaretta, az elektromos cigaretta és a vízipipa által kibocsátott és a légutak különböző régióiban leülepedett károsanyagmennyiségek összehasonlítása megtörténhessen. Feltételezve, hogy a nagyobb mennyiségű károsanyag-leülepedéshez nagyobb egészségügyi kockázat rendelhető, a folyamatban lévő modellezés elvezethet a három termék összehasonlító egészségügyi kockázatbecsléséhez.

Anyagi támogatás: A szerzők a közlemény megírásával kapcsolatban anyagi támogatásban nem részesültek.

Szerzői munkamegosztás: F. Á.: A koncepció és a módszertan kidolgozása, irodalomkutatás, a kézirat megírása. T. G., H. A.: A koncepció és a módszertan kidolgozása, irodalomkutatás, a kézirat szerkesztése. K. E.: A szakirodalom elemzése, a kézirat szerkesztése. A cikk végleges változatát valamennyi szerző elolvasta és jóváhagyta.

Érdekeltségek: A szerzőknek nincsenek érdekeltségeik.

\section{Irodalom}

[1] WHO report on the global tobacco epidemic, 2019. World Health Organization, Geneva, 2019.

[2] Fluharty M, Taylor AE, Grabski M, et al. The association of cigarette smoking with depression and anxiety: a systematic review. Nicotine Tob Res. 2017; 19: 3-13.
[3] Boksa P. Smoking, psychiatric illness and the brain. J Psychiatry Neurosci. 2017; 42: 147-149.

[4] Mappin-Kasirer B, Pan H, Lewington P, et al. Tobacco smoking and the risk of Parkinson disease. A 65-year follow-up of 30,000 male British doctors. Neurol. 2020; 94: e2132-e2138.

[5] Papathanasiou G, Mamali A, Papafloratos S, et al. Effects of smoking on cardiovascular function: the role of nicotine and carbon monoxide. Health Sci J. 2014; 8: 272-288.

[6] Linneberg A, Jacobsen RK, Skaaby T, et al. Effect of smoking on blood pressure and resting heart rate: a Mendelian randomization meta-analysis in the CARTA consortium. Circ Cardiovasc Genet. 2015; 8: 832-841.

[7] Bank E, Joshy G, Korda RJ, et al. Tobacco smoking and risk of 36 cardiovascular disease subtypes: fatal and non-fatal outcomes in a large prospective Australian study. BMC Med. 2019; 17: 128.

[8] Niemann B, Rohrbach S, Miller MR, et al. Oxidative stress and cardiovascular risk: obesity, diabetes, smoking, and pollution. J Am Coll Cardiol. 2017; 70: 230-251.

[9] Terzikhan N, Verhamme KM, Hofman A, et al. Prevalence and incidence of COPD in smokers and non-smokers: the Rotterdam study. Eur J Epidemiol. 2016; 31: 785-792.

[10] Leem AY, Park B, Kim YS, et al. Longitudinal decline in lung function: a community-based cohort study in Korea. Sci Rep. 2019; 9: 13614 .

[11] Goldkorn T, Filosto S, Chung S. Lung injury and lung cancer caused by cigarette smoke-induced oxidative stress: molecular mechanisms and therapeutic opportunities involving the ceramide-generating machinery and epidermal growth factor receptor. Antioxid Redox Signal. 2014; 21: 2149-2174.

[12] Barnes PJ. Senescence in COPD and its comorbidities. Annu Rev Physiol. 2017; 79: 517-539.

[13] Hikichi M, Mizumura K, Maruoka S, et al. Pathogenesis of chronic obstructive pulmonary disease (COPD) induced by cigarette smoke. J Thorac Dis. 2019; 11(Suppl 17): S2129-S2140.

[14] Postma DS, Kerkhof M, Boeze HM, et al. Asthma and chronic obstructive pulmonary disease: common genes, common environments? Am J Respir Crit Care Med. 2011; 183: 1588-1594.

[15] Janzen B, Karunanayake C, Rennie D, et al. Gender differences in the association of individual and contextual exposures with lung function in a rural Canadian population. Lung 2017; 195: 43-52.

[16] Moazed F, Calfee CS. Clearing the air. Smoking and incident asthma in adults. Am J Respir Crit Care Med. 2015; 191: 123124.

[17] Chatkin JM, Dullius CR. The management of asthmatic smokers. Asthma Res Pract. 2016; 2: 10.

[18] Harju M, Keski-Nisula L, Georgiadis L, et al. Parental smoking and cessation during pregnancy and the risk of childhood asthma. BMC Public Health 2016; 16: 428.

[19] O'Byrne P, Fabbri LM, Pavord ID, et al. Asthma progression and mortality: the role of inhaled corticosteroids. Eur Respir J. 2019; 54: 1900491

[20] Tomisa G, Horváth A, Szalai Z, et al. Prevalence and impact of risk factors for poor asthma outcomes in a large, specialist-managed patient cohort: a real-life study. J Asthma Allergy 2019; 12: 297-307.

[21] Lubin JH, Steindorf K. Cigarette use and the estimation of lung cancer attributable to radon in the United States. Radiat Res. 1995; 141: 79-85.

[22] Fogarasi-Grenczer A, Balázs P. The correlation between smoking, environmental tobacco smoke and preterm birth. [A dohányzás és a környezeti dohányfüstártalom kapcsolata a koraszülésekkel.] Orv Hetil. 2012; 153: 690-694. [Hungarian]

[23] Perry MF, Mulcahy H, DeFranco EA. Influence of periconception smoking behaviour on birth defect risk. Am J Obstet Gynecol. 2019; 220: 588.el-588.e7. 
[24] Berkowitz L, Schultz BM, Salazar GA, et al. Impact of cigarette smoking on the gastrointestinal tract inflammation: opposing effects in Chron's disease and ulcerative colitis. Front Immunol. 2018; 9: 74 .

[25] Alqahtani JS, Oyelade T, Aldhahir AM, et al. Prevalence, severity and mortality associated with COPD and smoking in patients with COVID-19: a rapid systematic review and meta-analysis. PLOS ONE 2020; 15: e0233147.

[26] Sanyaolu A, Okorie C, Marinkovic A, et al. Comorbidity and its impact on patients with COVID-19. SN Compr Clin Med. 2020 Jun 25. Doi: 10.1007/s42399-020-00363-4. [Epub ahead of print]

[27] Wallace AM, Foronjy RE. Electronic cigarettes: not evidencebased cessation. Transl Lung Cancer Res. 2019; 8(Suppl 1): S7S10.

[28] Euromonitor International. Global tobacco key findings Part 2: Vapour products. Available from: https://www.euromonitor. com/global-tobacco-key-findings-part-2-vapour-products/report [accessed: August 7, 2020].

[29] Cselkó Zs, Pénzes M. Summary of the existing knowledge about electronic cigarettes. [Az elektronikus cigarettáról meglévố ismeretek összefoglalása.] Orv Hetil. 2016; 157: 979-986. [Hungarian]

[30] Cervellati F, Muresan XM, Sticozzi C, et al. Comparative effects between electronic and cigarette smoke in human keratinocytes and epithelial lung cells. Toxicol In Vitro 2014; 28: 999-1005.

[31] Park HR, O'Sullivan M, Vallarino J, et al. Transcriptomic response of primary human airway epithelial cells to flavoring chemicals in electronic cigarettes. Sci Rep. 2019; 9: 1400.

[32] Czogała J, Cholewiński M, Kutek A, et al. Evaluation of changes in hemodynamic parameters after the use of electronic nicotine delivery systems among regular cigarette smokers. [Ocena zmian wybranych parametrów hemodynamicznych po użyciu elektronicznych inhalatorów nikotyny wśród regularnych palaczy papierosów.] Przegl Lek. 2012; 69: 841-845. [Polish]

[33] Palamidas A, Tsikrika S, Katsaounou PA, et al. Acute effects of short term use of e-cigarettes on airways physiology and respiratory symptoms in smokers with and without airway obstructive diseases and in healthy non smokers. Tob Prev Cessat. 2017; 3: 5 .

[34] Pisinger C, Døssing M. A systematic review of health effects of electronic cigarettes. Prev Med. 2014; 69: 248-260.

[35] Nagy LB. What we know from the harmful effects of e-cigarettes? [Mit tudunk az e-cigaretta káros hatásairól?] Orv Hetil. 2019; 160: 1767-1773. [Hungarian]

[36] Abafalvi L, Pénzes M, Urbán R, et al. Perceived health effects of vaping among Hungarian adult e-cigarette-only and dual users: a cross-sectional internet survey. BMC Public Health 2019; 19: 302.

[37] Xantus G, Gyarmathy VA, Kanizsai P. Actual questions about the electronic cigarette associated lung injury. [Égető kérdések.
Merre tartunk az e-cigarettázással összefüggésbe hozható tüdőbetegséggel?] Orv Hetil. 2020; 161: 1281-1285. [Hungarian]

[38] Xantus G, Kanizsai PL. Vaping-associated lung injury. [Az e-cigarettázással összefüggésbe hozható tüdőbetegség.] Orv Hetil. 2020; 161: 413-418. [Hungarian]

[39] Balogh E, Faubl N, Riemenschneider H, et al. Cigarette, waterpipe and e-cigarette use among an international sample of medical students. Cross-sectional, multicenter study in Germany and Hungary. BMC Public Health 2018; 18: 591.

[40] WHO Study Group on Tobacco Product Regulation (TobReg). Waterpipe tobacco smoking: health effects, research needs and recommended actions by regulators. ISBN 9241593857 . World Health Organization, Geneva, 2005.

[41] Antus B, Barta I. Comparison of carbon monoxide between waterpipe and cigarette smokers. [Kilélegzett szén-monoxid szint összehasonlítása vízipipázók és cigarettázók között]. Med Thorac. 2017; 70: 287-294. [Hungarian]

[42] Bentur L, Hellou E, Goldbart A, et al. Laboratory and clinical acute effects of active and passive indoor group water-pipe (narghile) smoking. Chest 2014; 145: 803-809.

[43] Sibai AM, Tohme RA, Almedawar MM, et al. Lifetime cumulative exposure to waterpipe smoking is associated with coronary artery disease. Atherosclerosis 2014; 234: 454-460.

[44] Al-Osaimi A, Obaid O, Al-Asfour Y, et al. The acute effect of shisha smoking on oxygen saturation level and heart rate. Med Princ Pract. 2012; 21: 588.

[45] Boskabady MH, Farhang L, Mahmodinia M, et al. Comparison of pulmonary function and respiratory symptoms in water pipe and cigarette smokers. Respirology 2012; 17: 950-956.

[46] She J, Yang P, Wang Y, et al. Chinese water-pipe smoking and the risk of chronic obstructive pulmonary disease. Chest 2014; 146: 924-931.

[47] Dar NA, Bhat GA, Shah IA, et al. Hookah smoking, nass chewing, and oesophageal squamous cell carcinoma in Kashmir, India. Br J Cancer 2012; 107: 1618-1623. [Erratum: Br J Cancer 2013; 108: 1552.]

[48] Hosseini M, SeyedAlinaghi S, Mahmoudi M, et al. A case-control study of risk factors for prostate cancer in Iran. Acta Med Iran. 2010; 48: 61-66.

[49] Nuwayhid IA, Yamout B, Azar G, et al. Narghile (hubble-bubble) smoking, low birth weight, and other pregnancy outcomes. Am J Epidemiol. 1998; 148: 375-383.

[50] Hannoun A, Nassar AH, Usta IM, et al. Effect of female nargile smoking on in vitro fertilization outcome. Eur J Obstet Gynecol Reprod Biol. 2010; 150: 171-174.

(Farkas Árpád dr., Budapest, Konkoly-Thege Miklós út 29-33., 1121 e-mail: farkas.arpad@ek-cer.hu)

A cikk a Creative Commons Attribution 4.0 International License (https://creativecommons.org/licenses/by/4.0/) feltételei szerint publikált Open Access közlemény, melynek szellemében a cikk bármilyen médiumban szabadon felhasználható, megosztható és újraközölhető, feltéve, hogy az eredeti szerző és a közlés helye, illetve a CC License linkje és az esetlegesen végrehajtott módosítások feltüntetésre kerülnek. (SID_1) 